\title{
Overvoltages in MV Industrial Grid under Ground Faults
}

\author{
Yuriy Varetsky ${ }^{*}$ \\ Lviv Polytechnic National University, 12 Stepana Bandery St., Lviv, 79013, Ukraine
}

Received: October 18, 2019. Revised: November 27, 2019. Accepted: December 13, 2019.

(C) 2019 The Author. Published by Lviv Polytechnic National University.

\begin{abstract}
Medium voltage distribution power grids mostly operate with ungrounded neutral points of transformers. The philosophy of these electrical grids is based on the assumption that they are more reliable than grids with grounded neutral. However, transient currents during single phase or multiple faults to ground, depending mostly on the phase to ground capacitances of the used cables connected to power grid substation buses, frequently have intermittent nature due to arising arc. Moreover, this kind of arc ground fault on the ungrounded system causes transient overvoltages significantly higher than the nominal value. In the consequence, it may be dangerous for the electrical devices connected to the power system. The article focuses on the transient overvoltages on the adjustable speed drives due to ground faults within the industrial grid. The Matlab/Simulink Software was used for modeling system transients during intermittent faults.
\end{abstract}

Keywords: electrical grid; grounding methods; transient overvoltage; transient intermittent faults.

\section{Introduction}

Industrial plants use many types of grounding methods in medium-voltage (MV) distribution systems which depend on their type (consisting cable, overhead or both lines), operating conditions and structures. These grounding methods can be usually categorized into the following two groups [1], [2]:

1) large-current grounding:

- effective (solid) grounding,

- low-impedance grounding.

2) small-current grounding:

- ungrounded or isolated neutral,

- high-resistance grounded,

- resonant grounded.

Nowadays, there are two dominant grounding methods for medium-voltage distribution power grids: the multi grounded method (extensively used in North America) and the resonant-grounded and ungrounded methods (mainly used in Europe). Other grounding methods, such as high-resistance grounding, are more popular in industrial plants where service continuity is a main consideration to prevent costly process shutdowns.

The main objectives of system grounding include: minimizing equipment overvoltage and thermal stress, provide safety of personnel, reduce interference to communications systems, assist quick detection and isolation of single phase to ground faults and maximize system economic returns. As the operating experience shows, in MV distribution systems single line to ground faults are predominantly observed. The persistent single line to ground arcing faults generate high transient overvoltages, cause frequent equipment insulation failures, and propagate to multi phase faults. These are distinguished as bolted (solidly connected to ground) and arcing faults. The arcing faults usually caused by insulation breakdown, creating an arc between a phase and ground. When a distribution overhead

* Corresponding author. Email address: j.varetsky@gmail.com

This paper should be cited as: Y. Varetsky. Overvoltages in MV industrial grid under ground faults. Energy Engineering and Control Systems, 2019, Vol. 5, No. 2, pp. 75 - 80. https://doi.org/10.23939/jeecs2019.02.075 
grid is simple, it usually runs with isolated neutral to the ground. Because of its small distributed capacitance, the isolated neutral grid has the ability of self-extinction of arcing ground fault due to small fault current. As a grid expands, its distributed capacitance increases and supports ground fault arc burning.

When an ungrounded system contains an extensive network of cables and lines, the system resultant line to ground capacitance may be so large that arcing ground faults cannot self-extinguish. Using an inductor to ground the neutral point of the system allows compensating the capacitive fault current. Due to the complete compensation condition (when the inductive reactance is equal to one-third of the system zero-sequence capacitive reactance), the grid achieves parallel resonance and the ground fault currents are normally under a few amperes [1]. The grounding inductor, which is also called a Petersen coil after its inventor W. Petersen, normally has several taps to tune to different systems. Modern designs of the device allow continuous tuning by positioning the core of the coil. To prevent a large neutral voltage shift, a resonantgrounded system normally operates as overcompensated and the inductive current through the coil is larger than the capacitive current. However, distribution systems are dynamic, and cables and lines are usually switched and one of installed several grounding coils can be out of service for maintenance. Therefore the conclusion is that resonant-grounded system can run at all possible compensation levels, as: overcompensated, under-compensated and 100 percent compensated. The source impedance can therefore change from inductive to capacitive or vice versa.

Medium voltage distribution power grids with resonant grounded neutrals can normally operate under a singleground fault condition and due to such idea the service reliability is high. It has been found that arcing ground faults can cause transient overvoltages several times higher than the normal voltage [3], [4], [5], which may be dangerous for the equipment connected to the substation buses. A result is the overall system cost is high because of equipment and devices which have to be line-to-line voltage rated. Moreover, this kind of system grid has to be monitored because of capacitances which continually changes as feeders are switched on and off [6]. In fact, the inductor variability is high and its inductance has to be slightly larger than the stray capacitance to avoid a true resonant condition. Otherwise, there can appear conditions to transient overvoltages.

The present paper deals with the modeling and analysis of transient overvoltages in industrial MV cable grid operated with resonant neutral grounding in case of single line to ground faults (SLGF). The comparative transient analysis has been carried out between the results of the examined supply system with several Petersen coil tunings. To analyze this phenomenon, the computer modeling has been chosen because there are known limitations in the field testing with respect to the power grid condition and the number of times that the test can be carried out.

\section{Description of the industrial grid}

The one-line diagram of the examined industrial power grid part is presented in Fig.1. Transient overvoltages within the grid were simulated under intermittent single line to ground faults at the point shown in the diagram.

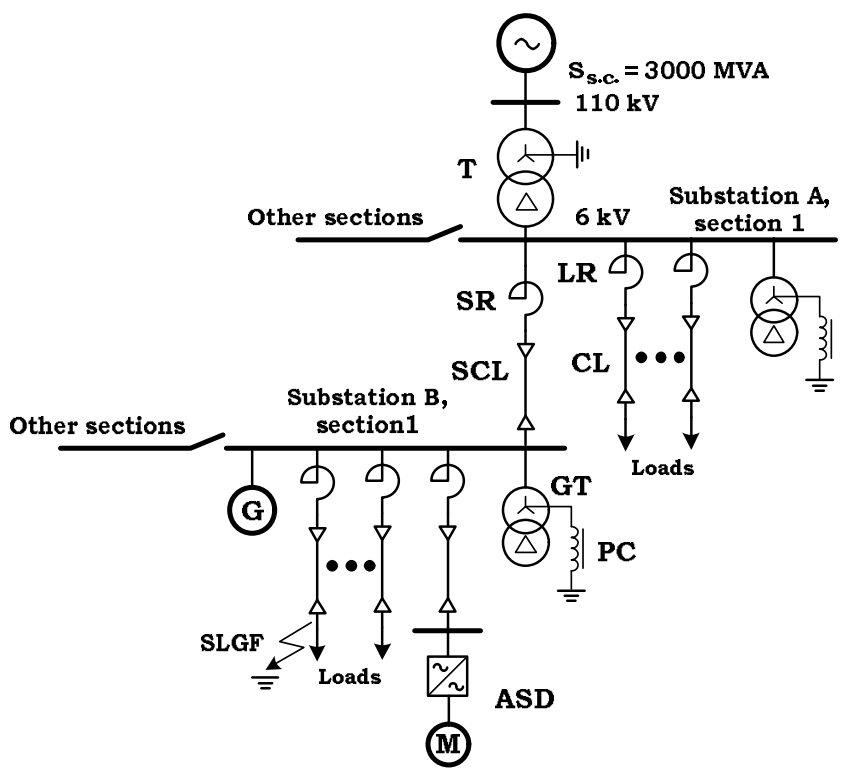

Fig.1. One-line diagram of the industrial power supply grid fragment. 
The power supply system $6 \mathrm{kV}$ is operated by two industrial substations. Substation A includes three sections and substation $\mathrm{B}$ includes four sections, that are connected to $110 \mathrm{kV}$ bus through three step-down power transformers TS of 31.5 MVA, having Yd11 connection groups of the windings. All sections of the substations are connected by intersection reactors of 2000 A rated current having percentage reactance of $10 \%$.

The sections supply linear and nonlinear loads via cable lines (CL) in series with load reactors (LR). The substation A of the industrial grid is connected to $6 \mathrm{kV}$ buses of the substation B by three parallel section cable lines (SCL) and section reactors (SR). The rated current of the cable lines is $2500 \mathrm{~A}$ and the line reactor inductance is $0.20 \mathrm{mH}$. Four turbogenerators $(\mathrm{G})$ of total capacity 37.5 MVA are connected to the sections of the substation B and supply the industrial loads too.

The analyzed grid is a very extensive industrial system; therefore due to complexity of connection topology of cable lines, transformers, induction and synchronous motors, it can operate in various topologies of connections between A and B substations. As it has been registered, damaging the cable insulation in this power supply system can cause the intermittent electric arc, which can lead to high amplitude of the transient overvoltage significantly higher than the phase voltage. This high overvoltage can damage the sensitive equipment, even if the system has the overvoltage protective devices.

All cables and reactors in the equivalent circuit of the grid are represented by their resistances, inductances and capacitances. Table 1 and 2 show the main parameters and equipment specification of the analyzed industrial grid.

Table 1. Equivalent parameters of the industrial grid.

\begin{tabular}{|l|c|c|}
\hline Parameter & Unit & Value \\
\hline Rated voltage, $\mathrm{U}_{\mathrm{n}}$ & $\mathrm{kV}$ & 6.00 \\
\hline Inductance of system, $\mathrm{L}_{\mathrm{s}}$ & $\mathrm{mH}$ & 0.34 \\
\hline Line-to-ground capacitance, $\mathrm{C}_{\mathrm{o}}$ & $\mu \mathrm{F}$ & 76.70 \\
\hline Line-to-line capacitance, $\mathrm{C}_{\mathrm{ll}}$ & $\mu \mathrm{F}$ & 28.30 \\
\hline
\end{tabular}

Table 2. Specification of the grid reactors.

\begin{tabular}{|c|c|c|c|c|}
\hline Type of reactor & $\begin{array}{c}\text { Rated voltage } \\
\mathrm{U}_{\mathrm{n}}[\mathrm{kV}]\end{array}$ & $\begin{array}{c}\text { Rated current } \\
\mathrm{I}_{\mathrm{n}}[\mathrm{kA}]\end{array}$ & $\begin{array}{c}\text { Resistance } \\
\mathrm{R}[\Omega]\end{array}$ & $\begin{array}{c}\text { Inductance } \\
\mathrm{L}[\mathrm{mH}]\end{array}$ \\
\hline Load reactor $(\mathrm{LR})$ & 6.00 & 0.60 & 0.35 & 0.45 \\
\hline Section reactor $(\mathrm{SR})$ & 6.00 & 1.00 & 0.27 & 1.10 \\
\hline
\end{tabular}

The above industrial power grid is operated with neutral points connected to the ground by Petersen coils installed at each neutral point of grounding transformers of the grid substations A and B. The each grounding transformer has the Petersen coil connected to the grounding transformer winding neutral and the coil is equipped with five manual taps. During analysis the grounding coils were set to the $3^{\text {rd }}$ tap of the coils. Table 3 shows the parameters of the resonant grounding system.

Table 3. Specification of the grounding transformer and coil.

\begin{tabular}{|c|c|c|c|c|}
\hline Unit & $\mathrm{S}_{\text {nom }}[\mathrm{kVA}]$ & $\mathrm{U}_{1},[\mathrm{kV}]$ & $\mathrm{U}_{2},[\mathrm{kV}]$ & $\mathrm{L}[\mathrm{mH}]$ \\
\hline Ground transformer $(\mathrm{GT})$ & 346 & 6.0 & 0.4 & 15.67 \\
\hline Petersen coil (PC) & 346 & 6.0 & - & 258.22 \\
\hline
\end{tabular}

The two adjustable speed drives (ASD) with total capacity of $500 \mathrm{~kW}$ are connected to the $6 \mathrm{kV}$ bus of B industrial substation via switchgears. The ASDs are supplied through load reactors (LR) and cable lines (CL) with rated current 1000 A. The ASD circuit diagram is presented in Fig.2. 


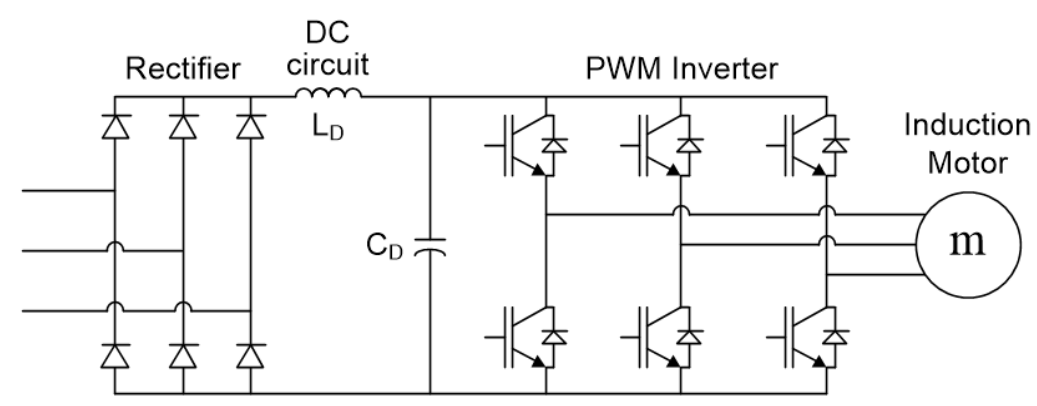

Fig.2. Adjustable speed drive circuit in the examined power supply system.

The capacitor of the ASD ensures smoothing DC voltage and links the ASD rectifier and inverter. The PWM inverter unit uses the $C_{D}$ capacitor voltage to create a variable frequency voltage to control the speed of the induction motor. The reactor $\mathrm{L}_{\mathrm{D}}$ of ASD is used to reduce the rate of the current rise due to rectifier is switching-on and provides the reduction of the overvoltage generated on the capacitor.

\section{Modelling intermittent fault}

This paper considers three phase simulation model included equivalent parameters of the system sources, power transformers, line reactors, cables and ASD circuit. Intermittent arcing fault at the cable grids has a stochastic nature and was modeled subject to the most influencing factors obtained from practical experience [7]. The arc model includes a series of successive arc ignitions and breaks in the faulted phase, as it has been described in [3], [4], [8]. Figure 3 shows the transient behavior during single line to ground fault under intermittent arc obtained by the analyzed grid model when grounding transformers are off. The line to ground voltages on the buses of the substation $\mathrm{B}$ are presented in the Figure 3A, fault current $\mathrm{I}_{\mathrm{SLGF}}$ is presented in the Figure 3B, and voltages at the ASD rectifier valves are presented in the Figure 3C. The arc ignitions and breaks occur at the 1 and 2 time points respectively, as they are shown in the Figure 3B. Successive recharges of the grid phase capacitance after each arc break cause phase voltage rise with adding the grid natural frequency transient voltage component.

The grid natural frequency $f$ allows estimating the equivalent resistor frequency dependence in the equivalent circuit for the proper accounting for the damping rate in the transient simulations [8], [9]. Using the value of the frequency, the model equivalent resistances $r_{f}$ were calculated by the below formula:

$$
r_{f}=r_{0} \sqrt{\frac{f}{f_{0}}}
$$

where $r_{0}$ the is the resistance at power system frequency $f_{0}$.

The grid natural frequency $f$ during intermittent arcing SLGF can be estimated by values of three phase short circuit current $I^{(3)}$ and the steady-state SLGF current $I^{(1)}$ at the fault point:

$$
f=f_{0} \sqrt{\frac{I^{(3)}}{I^{(1)}}} .
$$

\section{Results of simulations}

In the course of computer simulation of the analyzed industrial grid, the influence of the grid parameters on transient overvoltages on the ASD rectifier valves was studied. The parameters vary depending on the grid configurations under different operating requirements and the degree of compensation of the steady-state SLGF current. As it has been shown in the previous section of the paper, the intermittent arcing SLGF causes oscillating overvoltages on the ASD rectifier valves when grounding transformers with compensating coils are disconnected from the grid busses. According to Fig.3C, the overvoltage peak on the faulted phase reaches 1.74 relative to the magnitude of the valve steady voltage. Such level of the overvoltage can trigger the rectifier valve protection and tripping the ASD from the buses. 


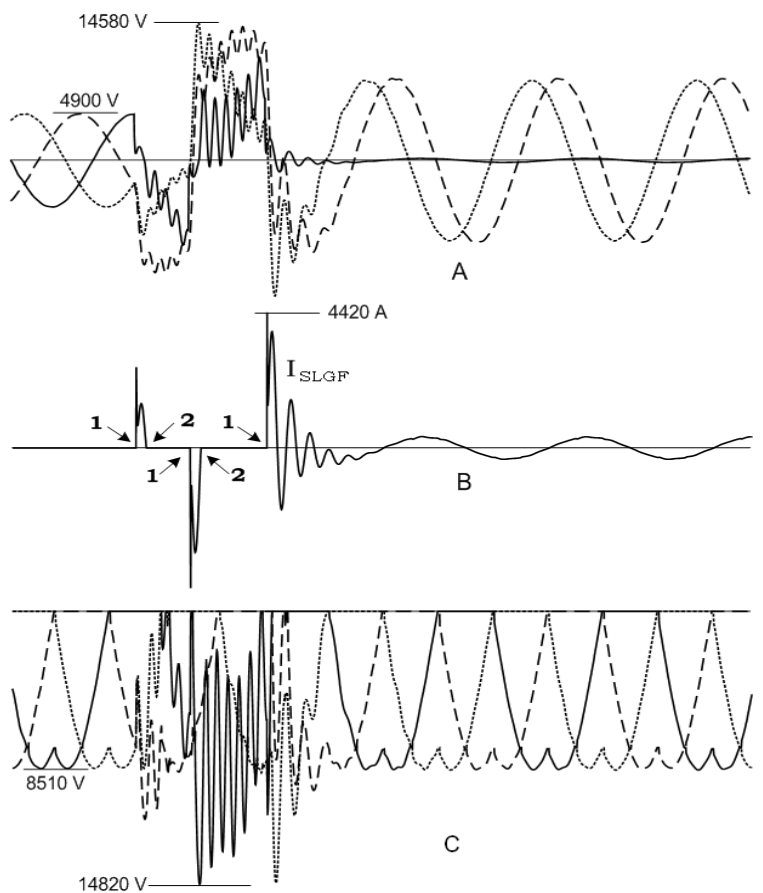

Fig.3. Transients in the grid when grounding transformers are off.
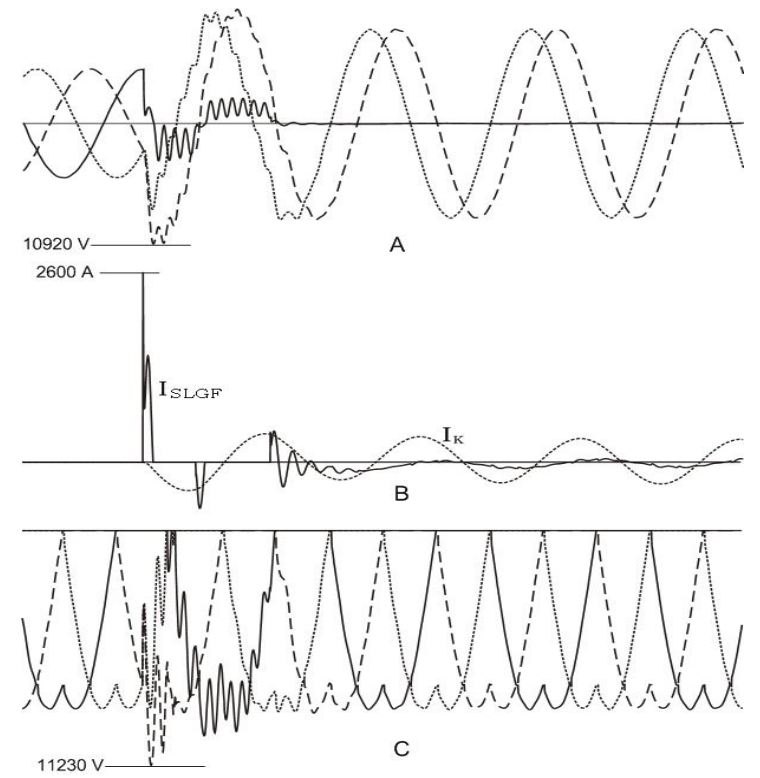

Fig.4. Transients in the grid at complete compensation of the SLGF steady curren.t

Figure 4 shows the transients in the grid when grounding transformers with compensating coils are connected to the substation buses and the setting up of the compensating coils provides almost complete compensation of the steady-state SLGF current. The current $I_{K}$ in the Figure 4B is the equivalent compensating coils current. In this operating state, the compensating coils increase the rate of discharge of the grid capacity after each arc pulse, and therefore the transient voltage does not rise to levels as in the previous case without compensation. The maximum rectifier valve overvoltage ratio in this case does not exceed 1.32 of the valve steady voltage magnitude.
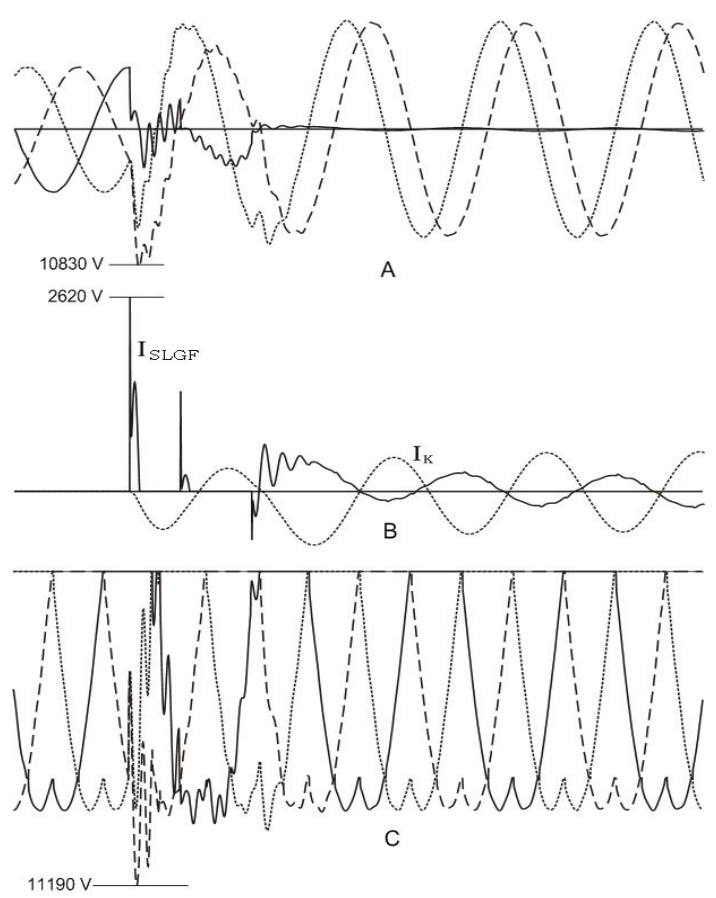

Fig.5. Transients in the grid at under-compensation of the SLGF steady-state current.
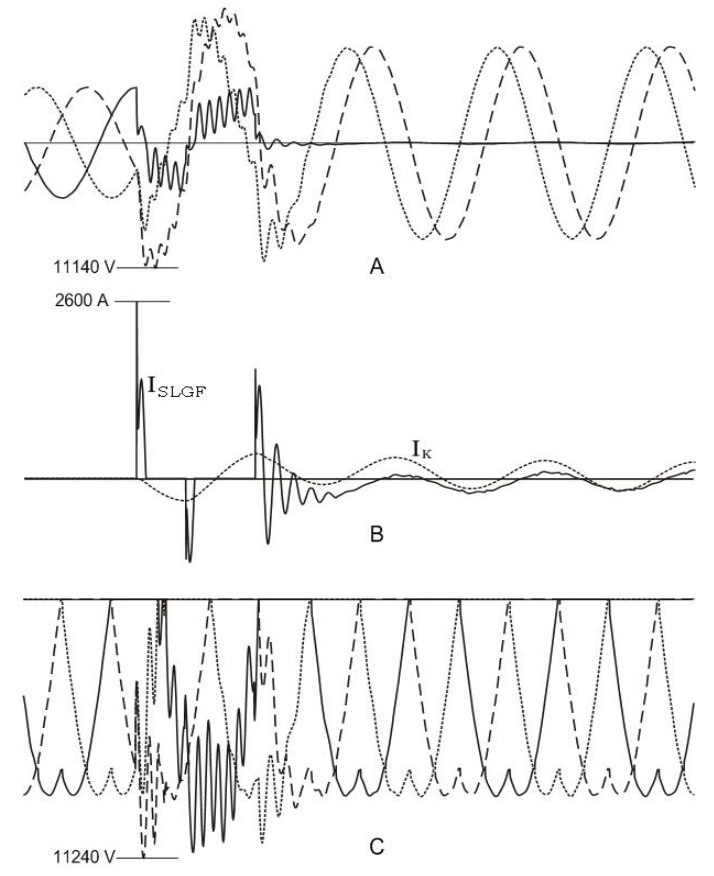

Fig.6. Transients in the grid at overcompensation of the SLGF steady-state current. 
Figure 5 and 6 present the transients in the grid when the setting up of the Petersen coils in the industrial grid provides under-compensation of the SLGF steady-state current by $30 \%$ and overcompensation of the current by $30 \%$ respectively. In spite of some difference in the transient behaviors, the similar impact of the Petersen coils on the transient nature can be observed: they decrease the transient overvoltage on the grid buses and rectifier valves, regardless of the compensation degree of the grid capacitive current.

\section{Conclusion}

Transient overvoltage magnitudes across the substation buses in the middle voltage resonantly grounded industrial power supply grid during single line to ground faults were investigated by computer simulation. There is presented a comparison of transients in a grid with compensating Petersen coils, which contains variable speed drives.

The results of simulating transients in the industrial grid have shown that compensating Petersen coils reduce the transient overvoltages under arcing single line to ground faults compared to an uncompensated grid with isolated neutral. Varying the grid parameters under different operating requirements can change the degree of compensation of the grid SLGF steady-state capacitive current. Studying transient overvoltages in the grid with different degree of under-compensation and overcompensation SLGF capacitive current has shown a minor impact of the Petersen coil tuning on the overvoltage level. In the examined power supply system comprising ASD, one can see the similar reduction of the transient overvoltages at different Petersen coil inductances.

\section{References}

[1] Hou D. Comparing Fault Resistance Coverage of Different Distribution System Grounding Methods. $37^{\text {th }}$ Annual Western Protective Relay Conference, October 2010.

[2] Agrawal K.C. Electrical Power Engineering Reference \& Applications Handbook. Chapter 20. Temporary over-voltages and system grounding, 2007, p. 759-772.

[3] Varetsky Y., Seheda M., Taran I. Modeling transients in compensated electrical grids during line faults. Proceedings - Int.Conf. on Modern Electric Power Systems, MEPS 2015, Wroclaw, Poland - July 6-9, 2015.

[4] Varetsky Y., Gapanovych V., Fedonjuk M. Modeling transient surge on filter reactor during external earth faults. Poznan University of Technology Academic Journals. Electrical Engineering, No.80, 2010. - P.65-66.

[5] Ravlić S., Marušić A. Simulation Models for Various Neutral Earthing Methods in Medium Voltage Systems. 25th DAAAM Int. Symp. on Intelligent Manufacturing and Automation, DAAAM 2015, Procedia Engineering 100 (2015), p. 1182-1191.

[6] Feng S., Zheng L., Lie J., Sun Y., Chen G., Ji X. Research on Arc-grounding Overvoltage in the 10kV Distribution System. 2012 Int. Conf. on Future Energy, Environment, and Materials, Energy Procedia 16 (2012), p. 1785-1791.

[7] Beliakov N.N. Studying voltages during arcing line to ground faults in 6-10 kV networks. Electrichestvo, 1957, No. 5, p. 31-36. (in Russian)

[8] Varetsky Y., Bachor Z., Ravlyk A. Transients in 10-35 kV electric networks with ungrounded neutrals under earth faults. Proc. of VII Int. Symp. „Short Circuit Currents in Power Systems”, Warsaw, 1996, p. 1.20.1-1.20.4.

[9] Varetsky Y., Pavlyshyn R., Taran I. Transients due to capacitor switching in industrial supply system. Proc. of VII Science-Technical Conference SIECI-2012, September 19-21, Szklarska Poreba, Poland, Paper 4.5, P.1-6.

\section{Перенапруги в промисловій мережі СН під час замикань на землю}

\section{Юрій Варецький}

Наџіональний університет “Львівська політехніка”, вул. Степана Бандери 12, м. Львів, 79013, Украӥна

\section{Анотація}

Електричні розподільні мережі середньої напруги в основному працюють 3 незаземленими нейтральними точками трансформаторів. Філософія цих електричних мереж базується на припущенні, що вони є більш надійними, ніж мережі з заземленою нейтраллю. Однак перехідні струми однофазних або багатократних замикань на землю, які в основному залежать від ємності фаз на землю використовуваних кабелів, що підключені до шин підстанцій електромережі, часто мають переривчастий характер внаслідок виникнення дуги. Більше того, такий тип дугового замикання на землю в незаземленій системі спричиняє значно вищі від номінальних перехідні перенапруги. Як наслідок, це може бути небезпечним для електричних пристроїв, підключених до цієї енергосистеми. Стаття присвячена перехідним перенапругам на електроприводах з регульованою швидкістю, які виникають внаслідок замикань на землю в промисловій мережі. Для моделювання перехідних процесів у системі під час переривистих замикань використовувалося програмне забезпечення Matlab/Simulink.

Ключові слова: електрична мережа; методи заземлення; перехідна перенапруга; перехідні переривчасті короткі замикання. 